
cited.

\title{
PERAN DAN TANGGUNG JAWAB NOTARIS DALAM MEMBERIKAN PENYULUHAN HUKUM KEPADA CALON KLIEN TERKAIT PEMBUATAN AKTA (CONTOH KASUS: PUTUSAN NOMOR 200/PDT.G/2012/PN.JKT.SEL.)
}

\begin{abstract}
Boy Nurdin
(Dosen Fakultas Hukum Universitas Tarumanagara. Meraih Sarjana Hukum pada Fakultash Hukum Universitas Nasional, Magister Hukum pada Fakultas Hukum Universitas Tarumanagara, Doktor (Dr.) pada Fakultas Hukum Universitas Padjadjaran)

(E-mail: boynurdin_pascaubhara@yahoo.com)
\end{abstract}

\section{Stephanie Lorenza}

(Mahasiswa Program S1 Fakultas Hukum Universitas Tarumanagara)

Received: 20 Agustus 2019; Accepted: 03 September 2019; Published: 29 Oktober 2019

\begin{abstract}
The growth of people which impacted the social life causes many events and legal actions, therefore peoples make agreements stated in deed. However, a few of them does not clearly understand what kind of deed to be made. That raises some issues, how important is the role of the notary in providing legal counseling to prospective clients in making the deed? And what about the notary responsible in providing legal counseling to prospective clients? The Author examined the issues by normative juridical research method. Notaries has a very important role to provide information related to the deed thus it can be made in accordance with applicable law, and the parties can feel safe and comfortable when implementing the agreement, and the partiies understand the contents of the deed signed by them, because based on Article 1338 of the Indonesian Civil Code states that "All legally executed agreements shall bind the individuals who have concluded them by law. They cannot be revoked otherwise than by mutual agreement, or pursuant to reasons which are legally declared to be sufficient. Theey shall be executed in good faith." A notary can be considered guilty if the notary on purpose does not provide legal counseling to parties who do not know the law in terms of the deed to be made, then the notary must be responsible for the deed he made. Thus, the sanction for the notary concerned is that the notary may become a defendant in relevant cases.
\end{abstract}

Keywords: Legal Counseling, Notary

\section{PENDAhULUAN}

\section{A. Latar Belakang}

Istilah negara hukum di

Indonesia secara konstitusional dapat kita lihat dalam Undang-Undang

Dasar Negara Republik Indonesia Tahun 1945. (yang selanjutnya disebut UUD NRI 1945). Khususnya 
Volume 17, No. 2, Oktober 2019 dalam Pasal 1 ayat (3) UUD NRI

1945 yang menyatakan bahwa

"Negara Indonesia adalah Negara

Hukum". Selain dalam Pasal 1 ayat

(3) UUD NRI 1945, terdapat

beberapa pernyataan yang

mencerminkan bahwa Indonesia

sebagai negara hukum antara lain:

1. Bab X Pasal 27 ayat (1) UUD NRI 1945 yang menyatakan bahwa "Segala warga Negara bersamaan kedudukannya di dalam hukum dan pemerintah wajib menjunjung hukum dan pemerintahan itu dengan tidak ada kecualinya", dan

2. Dalam Pasal 28 ayat (5) UUD NRI 1945 yang berbunyi bahwa "Untuk penegakkan dan melindungi hak asasi manusia sesuai dengan prinsip negara hukum yang demokratis, maka pelaksanaan hak asas manusia dijamin, diatur, dan dituangkan dalam peraturan perundangundangan".

Bukti lain yang menjadi dasar yuridis dalam arti material, tercantum pada Bab XIV Pasal 33 dan Pasal 34 UUD NRI 1945. Negara dalam hal ini berkontribusi aktif dan bertanggung jawab untuk kesejahteraan rakyat (kesejahteraan sosial). Konsep kesejahteraan sosial dapat kita lihat dalam Undang-Undang Nomor 11 Tahun 2009 tentang Kesejahteraan Sosial (yang selanjutnya disebut UU Kesejahteraan Sosial). Dalam Pasal 1 ayat (1) UU Kesejahteraan Sosial, didefinisikan bahwa

"Kesejahteraan sosial adalah kondisi terpenuhinya kebutuhan material, spiritual, dan sosial warga negara agar dapat hidup layak dan mampu mengembangkan diri sehingga dapat melaksanakan fungsi sosialnya.".

Fungsi sosial tersebut adalah kegiatan individu dalam masyarakat yang teratur dan terorganisasi baik di dalam suatu keluarga, kelompok, organisasi, daerah desa sampai pada negara dan mencakup pula: status/kedudukan, peranan, dan norma. Kesemua hal tersebut harus dilakukan dengan sadar dan penuh tanggung jawab agar hidup yang wajar dan harmonis dapat tercapai. Sejalan dengan hal tersebut, tugas dan peranan masing-masing individu pun mempunyai norma atau peraturan hukum. Jika tidak diatur, maka akan menimbulkan masalah-masalah dalam struktur masyarakat sosial. Norma atau peraturan hukum dalam hal ini 
Volume 17, No. 2, Oktober 2019 menjadi dasar bagi seseorang menjalankan peran atau status/kedudukan sehingga tidak bertentangan atau menyimpang dari segala hal yang telah diatur.

Hal tesebut berlaku juga bagi para notaris. Berdasarkan Pasal 1 angka 1 Undang-Undang Nomor 30 Tahun 2004 tentang Jabatan Notaris sebagaimana telah diubah dengan Undang-Undang Nomor 2 Tahun 2004 (yang selanjutnya disebut UU Jabatan Notaris), menyatakan bahwa: "Notaris adalah pejabat umum yang berwenang untuk membuat akta autentik dan memiliki kewenangan lainnya sebagaimana dimaksud dalam Undang-Undang ini atau berdasarkan undang-undang lainnya.". Menurut Abdul Ghofur Anshori, profesi notaris adalah suatu profesi yang mulia (nobile officium), karena akta yang dibuat oleh notaris dapat menjadi dasar hukum atas status harta benda, dan menjadi dasar hak dan kewajiban seseorang. Kekeliruan atas akta yang dibuat notaris dapat menyebabkan hilangnya hak seseorang atau menyebabkan terbebaninya seseorang atas suatu kewajiban. Dalam menjalankan tugas jabatannya seorang notaris harus mematuhi berbagai ketentuan yang tersebut dalam UU Jabatan Notaris. ${ }^{1)}$ Seorang notaris dalam menjalankan tugas dan jabatannya selain harus mematuhi ketentuan-ketentuan yang tersebut dalam UU Jabatan Notaris, juga harus tunduk kepada Kode Etik Notaris.

Pertumbuhan

masyarakat yang berpengaruh terhadap kehidupan sosial banyak menimbulkan peristiwa

maupun perbuatan hukum. Dalam peristiwa maupun perbuatan hukum tersebut, hanya masyarakat yang berkepentingan saja yang mempunyai hubungan dengan jabatan Notaris. Akan tetapi, masyarakat yang berkepentingan yang akan melalukan perbuatan hukum tersebut belum tentu memahami hukum, terutama mengenai peristiwa atau pun perbuatan hukum yang akan dilakukan oleh klien yang

1) Abdul Ghofur Anshori, Lembaga Kenotariatan Indonesia: Perspektif Hukum dan Etika, (Yogyakarta: UII Press, 2009), 46. 
bersangkutan sehingga relevan dan penting bagi seorang notaris untuk memberikan penyuluhan hukum kepada para penghadap, sebelum para penghadap melakukan perbuatan hukum. Seperti yang tertuang dalam Pasal 15 ayat (2) huruf e UU Jabatan Notaris, yang menyatakan bahwa:

"Selain kewenangan sebagaimana dimaksud pada ayat

Notaris

berwenang pula:

memberikan penyuluhan hukum

sehubungan dengan

Akta.".

Dengan demikian, dapat diketahui bahwa seorang notaris dalam menjalankan jabatannya memiliki wewenang untuk memberikan penyuluhan hukum dan penjelasanpenjelasan kepada para klien yang memiliki kepentingan sehubungan dengan pembuatan akta autentik yang dibuat.

\section{Pasal 15 ayat (2) huruf e UU} Jabatan Notaris tersebut memberikan dasar bagi notaris tentang penyuluhan hukum tanpa keharusan memperhatikan kepuasan atau tidak puasnya klien pada saat proses penyuluhan hukum. Ketertarikan peneliti justru dari ketiadaan notaris memperhatikan kepuasan atau tidak puasnya klien tersebut. Pemberian peran tersebut menjadi selaras dengan peran apabila pada saat pembacaan akta, klien telah memahami isi akta karena penjelasan hukum yang sebelumnya klien terima dari notaris. Klien dapat mengkritisi atau bertanya kepada notaris maksud suatu pasal diatur dalam akta tersebut. Di sisi lain, bahwa penyuluhan hukum juga memberikan kewajiban bagi klien memperhatikan dokumen-dokumen sebagai persyaratan sebuah akta akan dibuat. Hal yang menarik peneliti dari pemaparan tersebut adalah memberikan penyuluhan hukum kepada klien dalam rangka membuat akta. Pertimbangan peneliti melakukan penelitian ini karena adanya kemungkinan bahwa notaris tidak memberikan penyuluhan hukum sebagaimana yang tertulis dalam Pasal 15 ayat (2) huruf e UU Jabatan Notaris tersebut.

Akta Notaris dibuat sesuai dengan kehendak para klien untuk menjami hak dan kewajiban para pihak, 
kepastian, ketertiban dan perlindungan hukum para klien yang dapat digunakan sebagai alat bukti apabila terjadi sengketa di

Pengadilan karena pada kenyataannya tidak menutup kemungkinan Akta Notaris tersebut dipermasalahkan oleh para klien di kemudian hari. Sehingga Notaris sebagai pejabat umum yang berwenang untuk membuat akta otentik bertanggung jawab atas akta yang dibuat oleh dan/atau dihadapan notaris yang bersangkutan.

Sebagai contoh kasus adalah kasus dari putusan Nomor 2083 K/Pdt/2014 juncto 621/PDT/2013/PT.DKI juncto

200/Pdt.G/2012/PN.Jkt.Sel.

Kasus ini terjadi antara William Supit sebagai Penggugat melawan Yolanda Siswanto sebagai Tergugat, Anne Djoenardi, SH., MBA., sebagai Turut Tergugat. Penggugat merupakan pemilik sebidang tanah dengan sertipikat Hak Milik Nomor 2695/Grogol Utara seluas 2.333 Meter Pesegi atas nama William Supit. Tanah tersebut terletak di Jalan Permata Hijau Raya Blok AA Persil Nomor 8, Kelurahan Grogol Utara, Kecamatan Kebayoran Lama, Kotamadya Jakarta Selatan. Kasus ini bermula pada saat bulan September 2011 dimana Penggugat hendak menjual tanahnya tersebut untuk modal usaha, maka Penggugat

menghubungi agen properti agar tanah tersebut dapat segera terjual. Pada tanggal 10 September 2011 agen properti

mempertemukan Penggugat dengan Tergugat untuk berdiskusi mengenai harga dan jangka waktu pembayarannya. 
Harga tanah tersebut

disepakati

sebesar

Rp.49.000.000.000,00

(empat puluh

Sembilan milyar rupiah).

Setelah disepakati mengenai

harga serta tahap

pembayarannya, kemudian

Penggugat dan Tergugat

sepakat pada tanggal 12

September 2011 bertemu di

kantor Turut Tergugat untuk

melaksanakan dan menanda-

tangani Akta Perjanjian

Pengikatan Jual Beli (yang

selanjutnya disebut APPJB).

Sebelum melakukan APPJB,

pihak Turut Tergugat terlebih

dahulu

melakukan

pengecekan terhadap

sertipikat Hak Milik Nomor

2695/Grogol Utara,

ternyata tanah yang dimaksud

pernah diblokir dan Pajak

Bumi dan

Bangunan

atas tanah

tersebut

belum dibayar

oleh

Penggugat selama

10

(sepuluh) tahun.
Pada tanggal 12

September 2011, terbitllah APPJB Nomor 12 tanggal 12 September 2011 yang dibuat dihadapan Turut Tergugat. Namun Tergugat

tidak langsung melakukan pembayaran uang muka kepada Penggugat sebagaimana yang telah diperjanjikan dalam APPJB tersebut. Pada tanggal 21 September 2011, Penggugat mengajak Tergugat ke kantor Turut Tergugat untuk melaksanakan dan menandatangani Akta Jual Beli (yang selanjutnya disebut AJB) serta meminta Tergugat untuk melunasi pembelian tanah tersebut. Namun, Tergugat menolak menanda-tangani AJB karena dalam APPJB tidak ditentukan batas waktu untuk pelaksanaan AJB dan pembayaran pelunasan tanah tersebut.

Sehingga pada tanggal 22 September 2011, Penggugat dan agen properti mendatangi kantor Turut 
Tergugat untuk menanyakan isi akta yang tidak sesuai dengan yang dibacakan oleh Turut Tergugat dengan yang telah ditanda-tangani oleh Penggugat dan Tergugat. Pada saat itu, Penggugat protes kepada Turut Tergugat karena isi akta tidak sesuai dengan yang diutarakan pada saat pembuatan APPJB, dan Turut Tergugat menyarankan kepada Penggugat untuk membatalkan APPJB Nomor 12 Tanggal 12 September 2011, dengan alasan Tergugat wanprestasi, dan juga menyatakan bahwa menurut ketentuan yang belaku umum, tenggang waktu untuk melakukan pelunasan pembayaran jual beli tanah adalah paling lambat 1 (satu) bulan setelah dibuat/ditandatanganinya suatu APPJB. Oleh karena Turut Tergugat dalam membuat APPJB yang isinya tidak sesuai dengan kesepakatan para pihak maka Penggugat dan Tergugat dalam pembuatan AJB beralih ke notaris lain.

\section{Berdasarkan}

pemaparan latar belakang dan kasus di atas, maka diangkatlah judul jurnal ini, yaitu: "PERAN DAN TANGGUNG JAWAB NOTARIS DALAM MEMBERIKAN

PENYULUHAN HUKUM KEPADA CALON KLIEN TERKAIT PEMBUATAN AKTA (CONTOH KASUS: PUTUSAN NOMOR 200/PDT.G/2012/PN.JKT.S

EL.)"”.

\section{B. Perumusan Masalah}

Bertitik tolak dari uraian yang dikemukakan dalam latar belakang di atas, maka pokok permasalahan yang diangkat adalah sebagai berikut:

1. Bagaimana

peran notaris dalam memberikan penyuluha n hukum kepada calon klien terkait pembuatan 
Volume 17, No. 2, Oktober 2019

akta?

2. Bagaimana

tanggung jawab notaris

dalam memberikan

penyuluhan

hukum kepada calon

klien

terkait

pembuatan akta?

\section{Metode Penelitian}

Berdasarkan

permasalahan yang diteliti

oleh peneliti, maka jenis penelitian yang digunakan

oleh peneliti adalah

penelitian hukum yuridis

normatif, yakni

penelitian hukum yang

dilakukan dengan cara

meneliti bahan pustaka atau

data sekunder belaka. ${ }^{2)}$

Pendekatan yang digunakan

adalah pendekatan kualitatif,

yakni suatu tata cara

penelitian yang

menghasilkan data deskriptif,

yaitu apa yang dinyatakan

2) Soerjono Soekanto dan Sri Mamudji, Penelitian Hukum Normatif Suatu Tinjauan Singkat, (Jakarta: PT. Raja Grafindo Persada, 2009), 13-14. oleh responden

secara

tertulis atau lisan, dan

juga perilakunya nyata, yang

diteliti dan

dipelajari

sebagai sesuatu yang utuh. ${ }^{3)}$

Dalam penelitian ini, peneliti menggunakan bahan hukum primer, sekunder, dan tersier.

Teknik

pengumpulan data

yang

digunakan oleh Peneliti

adalah dengan melakukan

studi dokumen terhadap

bahan-bahan hukum primer, sekunder, dan terseier serta melakukan wawancara dengan Notaris dan Akademisi. Setelah data dan bahan hukum dikumpulkan, selanjutnya data akan diolah sedemikian rupa sehingga data dan bahan hukum tersebut tersusun secara sistematis, sehingga dapat memudahkan dalam melakukan analisis dalam penelitian ini. Teknik analisis yang dipergunakan dalam penelitian ini adalah

3) Soerjono Soekanto, Pengantar Penelitian Hukum, Cetakan ke-3, (Jakarta: UI Press, 2006), 32. 
metode analisis deskriptif, yakni digunakan untuk memberikan gambaran dan menganalisis subjek dan objek data-data sekunder.

\section{PEMBAHASAN}

\section{A. Peran Notaris Dalam Memberikan Penyuluhan Hukum Kepada Calon} Klien Terkait Pembuatan Akta

Berdasarkan Pasal 1 angka 1 UU Jabatan Notaris, "Notaris adalah pejabat umum yang berwenang untuk membuat akta otentik dan kewenangan lainnya sebagaimana

dimaksud dalam undangundang ini." Menurut Sudarsono, notaris adalah orang yang mendapat kuasa dari pemerintah untuk mengesahkan dan menyaksikan berbagai surat perjanjian, surat wasiat, akta, dan sebagainya berdasarkan penunjukan pemerintah
(Departemen Kehakiman). ${ }^{4}$

Dalam Pasal 2 UU Jabatan Notaris menyatakan bahwa "Notaris diangkat dan diberhentikan oleh Menteri." Menteri yang dimaksud dalam Pasal 2 UU Jabatan Notaris adalah Menteri yang bidang tugas dan tanggung jawabnya meliputi bidang kenotariatan, hal tersebut tercantum dalam Pasal 1 $\begin{array}{lll}\text { angka } & 14 \quad \text { UU }\end{array}$ Jabatan Notaris.

Sejalan dengan hal-hal tersebut, peneliti dalam penelitian ini berpendapat bahwa notaris merupakan seorang pejabat umum yang daingkat oleh Menteri yang bidang dan tanggung jawabnya meliputi bidang kenotariatan serta memiliki kewenangan berdasarkan penunjukan pemerintah untuk membuat akta yang diinginkan oleh pihak-pihak tertentu sehingga

4) Sudarsono, Kamus Hukum, Cetakan Ke-5, (Jakarta: PT Asdi Mahasatya, 2007), 307. 
menjadi suatu akta yang

menyatakan bahwa:

otentik dan sesuai dengan

ketentuan hukum yang

berlaku.

“(1) Notaris

berwenang

membuat Akta

autentik

Setiap kewenangan

mengenai

mempunyai

batasannya sebagaimana

yang tercantum dalam

peraturan perundang-

undangan yang mengaturnya.

Kewenangan Notaris terbatas

sebagaimana

peraturan perundang-

undangan yang

semua

perbuatan,

perjanjian, dan

penetapan yang

diharuskan oleh

peraturan

perundang-

undangan

dan/atau yang

dikehendaki

oleh yang

berkepentingan

untuk

mengatur jabatan Pejabat

yang bersangkutan. ${ }^{5)}$

Oleh karena itu, seorang

notaris dalam menjalankan

jabatannya terikat dengan

ketentuan-ketentuan

yang tersebut dalam UU

Jabatan Notaris, selain itu

notaris juga tunduk kepada

Kode Etik Notaris.

Kewenangan notaris

tercantum dalam Pasal 15 UU

Jabatan Notaris,

dinyatakan

dalam Akta

autentik,

menjamin

kepastian

tanggal

pembuatan

Akta,

menyimpan

Akta,

memberikan

grosse, salinan

dan kutipan

Akta, semuanya

itu sepanjang

pembuatan Akta itu tidak juga ditugaskan atau dikecualikan

kepada pejabat lain atau orang lain yang ditetapkan oleh undang undang.

5) Habib Adjie, Hukum Notaris Indonesia: Tafsir Tematik Terhadap UU No. 30 Tahun 2004 Tentang Jabatan Notaris, Cetakan ke-4, (Bandung: PT Refika Aditama, 2014), 77. 
Volume 17, No. 2, Oktober 2019

(2) Selain

kewenangan

sebagaimana

dimaksud pada

ayat

(1),

Notaris

berwenang

pula:

a. mengesah

kan tanda

tangan

dan

menetapk

an

kepastian

tanggal

surat di

bawah

tangan

dengan

mendaftar

dalam

buku

khusus;

b. membuku

kan surat

di bawah

tangan

dengan

mendaftar

dalam

buku

khusus;

c. membuat

kopi dari

asli surat

di bawah

tangan

berupa

salinan

yang

memuat

uraian

sebagaim

ana

ditulis dan

digambar

kan dalam

surat

yang

bersangku

tan;

d. melakuka

n

pengesah

an

kecocokan

fotokopi

dengan

surat

aslinya;

e. memberik

an

penyuluha

$n$ hukum

sehubung

an dengan

pembuata

n Akta;

f. membuat

Akta yang

berkaitan

dengan

pertanaha

$n$; atau

g. membuat

Akta

risalah

lelang.

(3) Selain

kewenangan

sebagaimana

dimaksud pada

ayat (1) dan

ayat

(2),

Notaris

mempunyai

kewenangan

lain yang diatur

dalam

peraturan 
perundang-

undangan."

Menurut Tan Thong

Kie, tugas Notaris adalah

mengkonstatir

hubungan hukum antara para

pihak dalam bentuk tertulis

dan format

tertentu,

sehingga merupakan suatu

akta otentik.

Notaris

adalah pembuat dokumen

yang kuat dalam suatu proses

hukum. ${ }^{6)}$ Menurut Supriadi,

tugas pokok seorang notaris

ialah membuat akta otentik,

baik yang ditentukan oleh

peraturan perundang-

undangan

maupun

oleh keinginan

orang

tertentu dan badan hukum yang memerlukannya. ${ }^{7)}$ Oleh

karena itu, sejalan dengan

ketentuan dari Pasal 15 ayat

(1) sampai ayat (3) UU

Jabatan Notaris dan

pendapat-pendapat tersebut,

6) Tan Thong Kie, Studi Notariat: Beberapa Mata Pelajaran dan Serba-Serbi Praktek Notaris, Buku I, Cetakan 2, (Jakarta: Ichtiar Baru Van Hoeve, 2007), 159.

7) Supriadi, Etika dan Tanggung Jawab Profesi Hukum di Indonesia, (Jakarta: Sinar Grafika, 2006), 37. maka peneliti berpendapat bahwa tugas pokok dari seorang notaris adalah membuat suatu akta otentik.

Dari

ketentuan tersebut juga dapat diketahui bahwa selain membuat suatu akta otentik, salah satu kewenangan notaris adalah memberikan penyuluhan hukum sehubungan dengan pembuatan Akta. Hal tersebut dinyatakan dalam Pasal 15 ayat (2) huruf e UU Jabatan Notaris. Menurut pendapat beberapa praktisi yang peneliti wawancarai, Ibu Dr. Tjempaka, S.H., M.H., M.Kn. berpendapat bahwa bentuk penyuluhan hukum yang diberikan oleh notaris kepada para calon klien adalah memberikan penjelasan hukum sesuai dengan koridor hukum terkait apa yang dibutuhkan oleh para calon klien yang bersangkutan tersebut. Ibu Dr. Lieke Lianadevi Tukgali, S.H., 
M.H., M.Kn. berpendapat bahwa bentuk penyuluhan hukum yang diberikan oleh notaris kepada para calon klien adalah memberikan penjelasan kepada para calon klien terkait apa yang para calon klien butuhkan pada saat bertemu dengan para klien yang bersangkutan, dengan kata lain notaris memberikan penjelasan terhadap apa yang dipertanyakan oleh para calon klien yang bersangkutan.

$$
\text { Apabila dikaitkan }
$$
dengan pendapat Herlien Budiono, yang menyatakan bahwa dalam banyak hal notaris berkududukan sebagai penasehat terpercaya dari orang-orang yang memerlukan bantuan hukum, dan bagi klien dapat berperan sebagai penunjuk arah. ${ }^{8)}$ Dengan

${ }^{8)}$ Herlien Budiono, Asas Keseimbangan Bagi Hukum Perjanjian Indonesia, Hukum Perjanjian Berlandaskan Asas-Asas Wigati Indonesia, (Bandung: Citra Aditya Bakti, 2006), 257. demikian, penyuluhan hukum yang dimaksud adalah pemberian informasi hukum sedalam-dalamnya mengenai akta yang dilakukan oleh notaris selama pemberian informasi hukum tersebut sesuai dengan koridor hukum yang berlaku.

Menurut Sudjana, metode penyuluhan hukum dapat dilakukan secara langsung (tatap muka) atau tidak langsung (melalui media elektronik atau cetak). ${ }^{9)}$ Penyuluhan hukum secara langsung dapat diselenggarakan dalam bentuk ceramah, diskusi, temu sadar hukum, pameran, simulasi, lomba kadarkum, konsultasi hukum, bantuan hukum, dan/atau bentuk lain. $^{10)}$ Menurut Ririk Eko

9) Sudjana, "Penyuluhan Hukum Dalam Upaya Peningkatan Kesadaran Hukum Berlalulintas Melalui Pemahaman Terhadap Isi Undang-Undang Nomor 22 Tahun 2009 Tentang Lalu Lintas Dan Angkutan Jalan”, Jurnal Pendidikan Ilmu Sosial, Volume 25 Nomor 2 Tahun 2016, 9.

${ }^{10)}$ Ibid. 


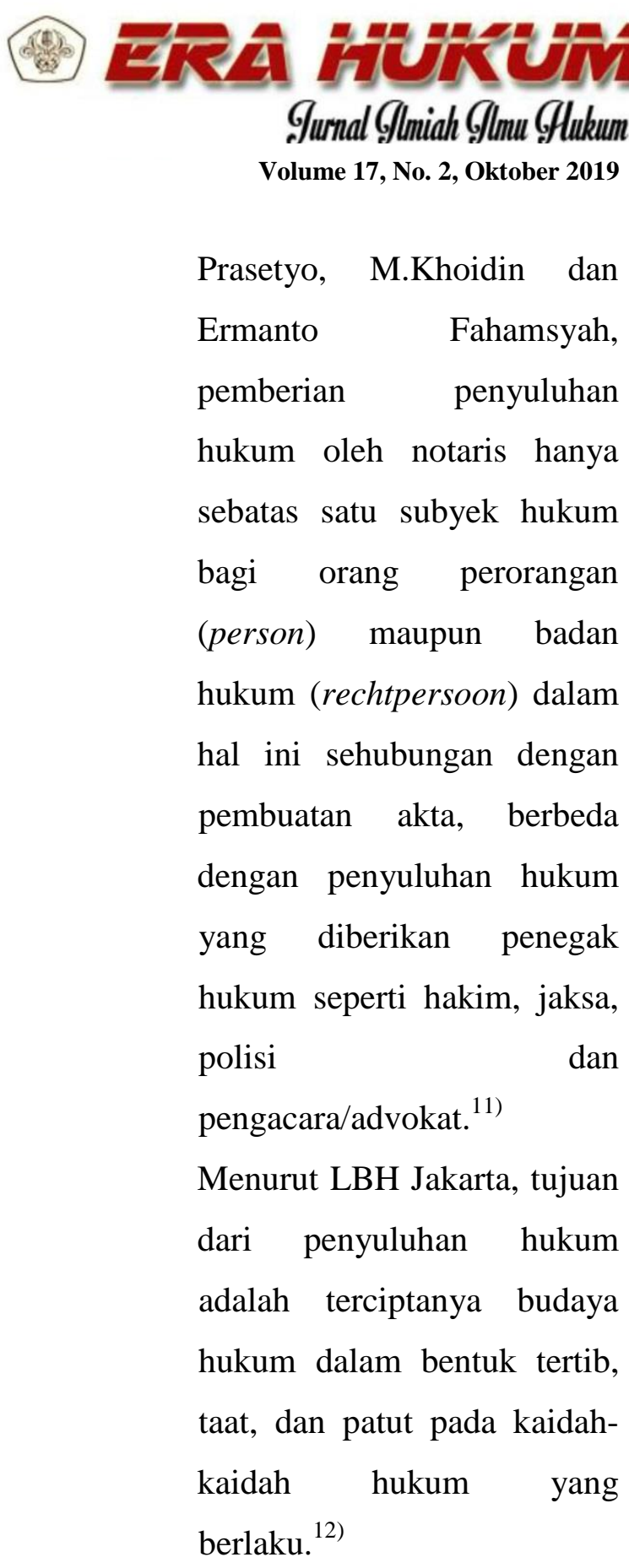

11) Ririk Eko Prasetyo et al., "Makna Pemberian Penyuluhan Hukum Oleh Notaris Pembuatan Akta Menurut Undang-Undang Jabatan Notaris", Lex Humana Jurnal Hukum dan Humaniora, Volume 1 Nomor 1 Tahun 2016, 58.

12) LBH Jakarta, "Penyuluhan Hukum LBH Jakarta Di Rutan Salemba", https://www.bantuanhukum.or.id/web/penyul uhan-hukum-lbh-jakarta-di-rutan-salemba/, Diakses pada Tanggal 1 Februari 2019.
Boy Nurdin \& Stephanie Lorenza

Peran dan Tanggung Jawab Notaris Dalam Memberikan Penyuluhan Hukum Kepada ....

Berdasarkan pendapat dari beberapa praktisi yang peneliti wawancarai, Ibu Dr. Tjempaka, S.H., M.H., M.Kn. berpendapat bahwa, penyuluhan hukum diberikan pada saat para klien yang bersangkutan hadir serta tujuan dilakukannya penyuluhan hukum adalah agar akta autentik yang dibuat dapat sesuai dengan hukum yang berlaku, agar para klien dapat merasa aman dan nyaman, dan untuk notaris bertujuan untuk melindungi dirinya sendiri dari akta yang dibuatnya. Bapak H.Nurdjaja, S.H. berpendapat bahwa penyuluhan hukum dilakukan secara verbal pada saat para pihak menghadap notaris sampai sebelum penandatanganan akta yang bersangkutan serta penyuluhan hukum bertujuan agar para pihak yang bersangkutan memahami akibat hukum yang para pihak sepakati dan 
Volume 17, No. 2, Oktober 2019

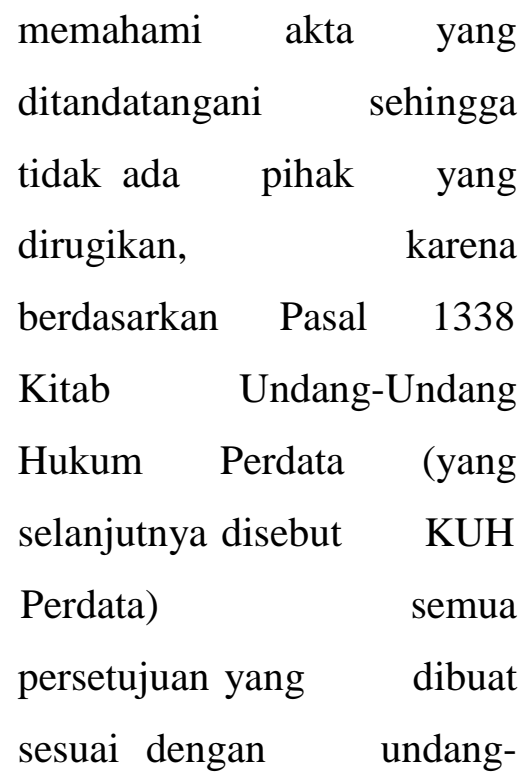

undang berlaku bagi mereka yang membuatnya.

Menurut

Abdul

Ghofur Anshori, profesi notaris adalah suatu profesi yang mulia (nobile officium), karena akta yang dibuat oleh notaris dapat menjadi dasar hukum atas status harta benda, dan menjadi dasar hak dan kewajiban seseorang.

Kekeliruan atas akta yang dibuat notaris dapat menyebabkan hilangnya hak seseorang atau menyebabkan terbebaninya seseorang atas suatu kewajiban. ${ }^{13)}$ Apabila dikaitkan dengan pendapat dari Komar Andasasmita, yang menyatakan bahwa tugas notaris memberikan bantuan tentang akta otentik. Sehingga penting bagi notaris untuk dapat memahami ketentuan yang diatur oleh undang-undang supaya masyarakat umum yang tidak tahu atau kurang memahami aturan hukum dapat memahami dengan benar serta tidak melakukan hal-hal yang bertentangan dengan hukum. ${ }^{14)}$

Sejalan dengan pendapat-pendapat tersebut, Peneliti berpendapat bahwa penyuluhan hukum harus dilakukan secara langsung atau tatap muka pada saat para klien yang bersangkutan menghadap notaris sehingga para klien yang bersangkutan dapat menanyakan lebih lanjut mengenai hal yang

\footnotetext{
13) Abdul Ghofur Anshori, Loc.Cit.

${ }^{14)}$ Komar Andasasmita, Notaris Selayang Pandang, Cetakan Ke-2, (Bandung: Bandung Alumni, 1983), 2.
} 
para klien kurang pahami.

Dengan demikian, akta yang dibuat oleh para klien dapat sesuai dengan hukum yang berlaku dan para klien pun dapat merasa aman dan nyaman pada saat menjalankan perjanjian yang dibuat olehnya. Selain itu, bagi notaris sendiri hal tersebut juga dapat menghindari kesalahan atau kekeliruan yang mungkin terjadi dalam hal pembuatan akta, sehingga Notaris dapat melindungi dirinya sendiri dari akta yang dibuatnya karena seorang notaris memiliki kewajiban untuk mempertanggung jawabkan semua akta yang dibuat olehnya.

\section{B. Tanggung Jawab Notaris} Dalam Memberikan

Penyuluhan Hukum

Kepada Calon Klien Terkait Pembuatan Akta

Pertumbuhan masyarakat yang berpengaruh terhadap kehidupan sosial banyak menimbulkan peristiwa maupun perbuatan hukum. Dalam peristiwa maupun perbuatan hukum tersebut, hanya masyarakat yang berkepentingan saja yang mempunyai hubungan dengan jabatan Notaris. Akan tetapi, masyarakat yang

berkepentingan yang akan melalukan perbuatan hukum tersebut belum tentu memahami hukum, terutama mengenai peristiwa atau pun perbuatan hukum yang akan dilakukan oleh klien yang bersangkutan sehingga relevan dan penting bagi seorang notaris untuk memberikan

penyuluhan hukum kepada para penghadap, sebelum para penghadap melakukan perbuatan hukum. Seperti yang tertuang dalam Pasal 15 ayat (2) huruf e UU Jabatan Notaris, yang menyatakan bahwa: "Selain kewenangan sebagaimana dimaksud pada Ayat (1), 
Notaris berwenang pula: memberikan penyuluhan hukum sehubungan dengan Akta.".

Oleh karena itu, seorang notaris mempunyai peran yang sangat penting dalam memberikan informasi terkait akta otentik sampai para pihak memahami mengenai akta yang ditandatanganinya, karena berdasarkan Oleh karena itu, seorang notaris mempunyai peran yang sangat penting dalam memberikan informasi terkait akta otentik sampai para pihak memahami mengenai akta yang ditandatanganinya, karena berdasarkan Pasal 1338 KUH Perdata yang menyatakan bahwa

"semua persetujuan yang dibuat sesuai dengan undangundang berlaku sebagai undang-undang bagi mereka yang membuatnya.

Persetujuan itu tidak dapat ditarik kembali selain dengan kesepakatan kedua belah pihak, atau karena alasanalasan yang ditentukan oleh undang-undang.

Persetujuan harus dilakukan dengan itikad baik".

Menurut

Anang Usman, Etika profesi adalah sebagai sikap hidup untuk memenuhi kebutuhan pelayanan professional dari klien dengan keterlibatan dan keahlian sebagai keseluruhan terhadap para anggota masyarakat yang membutuhkannya dengan disertai refleksi yang seksama. ${ }^{15)}$ Terdapat beberapa kaidah pokok berupa etika profesi menurut Keiser, yaitu: ${ }^{16)}$

1. profesi harus dipandang (dan dihayati) sebagai suatu pelayanan karena itu, maka sifat tanpa pamrih (disinterestedness)

15) M. Rizal J., "Pengertian Etika Profesi Menurut Para Ahli", https://www.scribd.com/document/366945832 /Pengertian-Etika-Profesi-Menurut-Para-Ahli, Diakses pada tanggal 17 Februari 2019

16) Suhrawardi K. Lubis, Etika Profesi Hukum, Cetakan Ke-10, (Jakarta: Sinar Grafika, 2017), 7. 
menjadi ciri khas dalam

mengembangkan profesi;

2. pelayanan professional dalam mendahulukan kepentingan klien mengacu kepada kepentingan atau nilainilai luhur sebagai norma kritik yang memotivasi sikap dan tindakan;

3. pengemban profesi harus selalu berorientasi pada masyarakat sebagai keseluruhan; dan

4. pengemban profesi harus bersemangat solidaritas antar sesama rekan seprofesi.

Sejalan dengan pendapat-pendapat tersebut, peneliti dalam penelitian ini berpendapat bahwa seorang notaris dalam memberikan pelayanan kepada para klien harus memiliki pandangan bahwa pelayanan tersebut merupakan sebuah pelayanan yang memiliki sifat tanpa pamrih dan seorang notaris harus selalu berorientasi pada masyarakat, maka seorang notaris harus selalu meningkatkan ilmu pengetahuan yang dimilikinya agar dapat mengikuti perkembangan hukum yang selalu dinamis.

Kewajiban

seorang notaris tercantum dalam Pasal 16 UU Jabatan Notaris. Dari ketentuan tersebut dapat diketahui bahwa salah satu kewajiban seorang notaris adalah memberikan pelayanan sesuai dengan ketentuan dalam Undang-Undang ini, kecuali ada alasan untuk menolaknya. Hal tersebut dinyatakan dalam Pasal 16 ayat (1) huruf e UU Jabatan Notaris. Oleh karena itu, seorang notaris harus memberikan pelayanan sesuai dengan ketentuan dalam UU Jabatan Notaris.

Menurut Ibu Dr. Tjempaka, S.H., M.H., M.Kn., memberikan penjelasan kepada klien tersebut diatur dalam Pasal 15 ayat (2) huruf e UU 
Jabatan Notaris

yang

menyatakan bahwa

"selain

kewenangan sebagaimana

dimaksud pada ayat (1),

Notaris berwenang pula:

memberikan penyuluhan

hukum sehubungan dengan

pembuatan Akta” dan Pasal

16 ayat (1) huruf e UU

Jabatan

Notaris yang

menyatakan

bahwa

"dalam menjalankan

jabatannya, Notaris wajib:

memberikan pelayanan

sesuai dengan ketentuan

dalam Undang-Undang ini,

kecuali ada alasan untuk

menolaknya.".

Sejalan dengan

pendapat dari Ibu Dr.

Tjempaka, S.H., M.H., M.Kn.

tersebut, peneliti dalam

penelitian ini berpendapat

bahwa seorang notaris dalam

menjalankan jabatannya wajib

memberikan pelayanan, salah

satunya adalah memberikan

penyuluhan hukum kepada

para klien sehubungan

dengan pembuatan Akta.
Menurut pendapat dari beberapa praktisi yang peneliti wawancarai, Ibu Dr. Lieke Lianadevi Tukgal, S.H., M.H., M.Kn berpendapat bahwa apabila notaris tidak memberikan penyuluhan hukum kepada para pihak, maka notaris tersebut dianggap bersalah. Hal serupa dikatakan oleh Bapak $\mathrm{H}$. Nurdjaja, S.H. Menurut Bapak H. Nurdjaja, S.H., notaris dapat dianggap bersalah apabila notaris tersebut tidak memberikan penyuluhan hukum kepada klien terkait akta yang akan dibuatnya dengan sengaja.

Akan tetapi, Ibu Dr. Tjempaka S.H., M.H., M.Kn., berpendapat bahwa Seorang notaris tidak dianggap bersalah apabila notaris tersebut tidak memberikan penyuluhan hukum bila para pihak telah mengetahui mengenai hukum dalam hal akta yang akan dibuatnya, hal tersebut terlihat dalam 
Pasal 16 ayat (1) huruf e UU

Jabatan Notaris.

Berdasarkan pendapat-

pendapat tersebut, peneliti

dalam penelitian ini

berpendapat bahwa seorang

notaris dapat dianggap

berasalah apabila notaris

tersebut tidak memberikan

penyuluhan hukum kepada

para pihak yang belum

mengetahui mengenai hukum

dalam hal akta yang akan

dibuatnya secara disengaja.

Sebagai contoh kasus

adalah kasus dari putusan

Nomor 2083 K/Pdt/2014

juncto 621/PDT/2013/PT.DKI

juncto

200/Pdt.G/2012/PN.Jkt.Sel.

Kasus ini terjadi antara

William Supit sebagai

Penggugat melawan Yolanda

Siswanto sebagai Tergugat,

Anne Djoenardi, SH., MBA.,

sebagai Turut Tergugat.

Kasus ini bermula pada awal

bulan September tahun 2011,

dimana William Supit

(Penggugat) yang merupakan

pemilik dari sebidang tanah dengan SHM Nomor 2695/Grogol Utara seluas

2.333 Meter Pesegi atas nama William Supit. Tanah tersebut terletak di Jalan Permata Hijau Raya Blok AA Persil Nomor 8, Kelurahan Grogol Utara, Kecamatan Kebayoran Lama, Kotamadya Jakarta Selatan. Dalam hal ini Penggugat hendak menjual tanahnya tersebut untuk modal usaha, sehingga Penggugat menghubungi Agent Property dengan tujuan agar tanah tersebut dapat cepat terjual, dimana kemudian Agent Property telah mendapat pembeli yang akan membeli tanah milik Penggugat tersebut diatas, yakni Yolanda Siswanto (Tergugat).

Pada tanggal 10 September 2011, Agent Property yakni ibu Sandrawaty Djuanda telah mempertemukan Penjual (Penggugat) dengan Pembeli (Tergugat)

untuk membicarakan harga 
maupun tenggang waktu

pembayarannya. Dalam

pertemuan tersebut telah

disepakati Penggugat sebagai

Penjual dan Tergugat sebagai

Pembeli mengenai harga tanah dan tenggang waktu pembayarannya. Pada tanggal

12 September 2011,

Penggugat dan Tergugat

bertemu di Kantor Notaris

Anne Djoenardi, SH., MBA.,

Notaris \& PPAT di Jakarta

(Turut Tergugat) untuk

melaksanakan dan

menandatangani APPJB. Oleh

karena pihak Turut Tergugat

telah melakukan pengecekkan

terlebih dahulu terhadap

SHM Nomor

2695/Grogol Utara seluas

2.333 Meter Pesegi atas

nama William Supit. Tanah

tersebut terletak di Jalan

Permata Hijau Raya Blok AA

Persil Nomor 8, Kelurahan

Grogol Utara, Kecamatan

Kebayoran Lama, Kotamadya

Jakarta Selatan, ternyata

diketahui bahwa tanah

tersebut pernah diblokir (namun kemudian blokir dimaksud sudah dicabut, dimana pencabutan pemblokiran atas sertifikat dimaksud diurus oleh Penggugat) serta Pajak

Bumi dan Bangunan atas tanah tersebut belum dibayar oleh Penggugat selama 10 (sepuluh) tahun.

Oleh karena pihak Tergugat merasa khawatir tidak dapat membeli tanah yang dimaksud, maka kemudian Tergugat merubah tata cara pembayaran sebagaimana yang telah disetujui pada tanggal 10 September 2011, sedangkan harga tanah tetap disepakati oleh Penggugat maupun Tergugat yaitu sebesar Rp.49.000.000.000,- (empat puluh sembilan milyar rupiah), sehingga tahap pembayarannya menjadi:

a. Dibayar oleh Tergugat kepada Penggugat secara tunai dan sekaligus sebesar Rp.5.000.000.000,- 
Volume 17, No. 2, Oktober 2019

(lima milyar rupiah)

pada saat penanda-

tanganan APPJB;

b. Sedangkan sisanya yakni

sebesar

Rp.44.000.000.000,-

(empat puluh empat

milyar rupiah) akan

dibayar tunai dan

sekaligus oleh Tergugat

kepada Penggugat pada

saat penanda-tanganan

AJB dengan syarat Pajak

Bumi dan Bangunan atas

tanah tersebut dibayar

lunas oleh Penggugat

sampai dengan tahun

2011, dimana pada saat

itu Penggugat berjanji

akan menyelesaikannya

paling lambat 1 (satu)

bulan setelah penanda-

tanganan

APPJB

dilaksanakan.

Pada tanggal

12

September 2011 tersebut,

Penggugat dan Tergugat

bertemu di Kantor

Turut Tergugat untuk

melaksanakan dan

menandatangani APPJB.
Namun, setelah APPJB tersebut telah ditanda-tangani oleh Tergugat maupun Penggugat, ternyata Tergugat tidak langsung melakukan pembayaran uang tahap pertama (uang muka) kepada Penggugat sebesar Rp.5.000.000.000,- _ima milyar rupiah) sebagaimana yang telah diperjanjikan dalam APPJB tersebut. Pada tanggal 13 September 2011 setelah Penggugat menagih uang tahap pertama (uang muka) sebesar Rp.5.000.000.000,- （lima milyar rupiah) kepada Tergugat, Tergugat baru kemudian melakukan pembayaran uang tahap pertama (uang muka) tersebut. Pada tanggal 21 September 2011, Penggugat mengajak Tergugat ke kantor Turut Tergugat untuk melaksanakan dan menandatangani AJB atas tanah dimaksud dan sekaligus meminta kepada Tergugat untuk melakukan pelunasan 
pembelian tanah tersebut yang masih tersisa sebesar Rp.44.000.000.000,- (empat puluh empat milyar rupiah), karena ternyata Penggugat dapat menyelesaikan pembayaran Pajak Bumi dan Bangunan atas tanah tersebut yang tertunggak sampai dengan tahun 2011, dalam waktu 1 (satu) minggu, sehingga pada tanggal 21 September 2011. Namun, Tergugat menolak untuk menanda-tangani AJB dengan beberapa alasan. Salah satu alasan Tergugat menolak untuk menandatangani AJB adalah karena dalam APPJB tanggal 12 September 2011, No. 12, tidak ditentukan batas waktu untuk pelaksanaan pembuatan AJB dan sekaligus pembayaran pelunasan harga tanah tersebut.

Oleh karena Penggugat sangat terkejut dengan alasan tersebut, maka pada tanggal $22 \quad$ September 2011
Penggugat dan Agent Property mendatangi Kantor Turut Tergugat untuk menanyakan isi akta yang tidak sesuai dengan yang dibicarakan oleh Turut Tergugat dengan yang telah ditanda-tangani oleh Penggugat dan Tergugat. Pada saat itu, Penggugat protes keras kepada Turut Tergugat atas isi akta yang tidak sesuai dengan yang diutarakan pada saat pembuatan APPJB, bahkan Turut Tergugat menyarankan kepada Penggugat untuk membatalkan APPJB, tanggal 12 September 2011, No. 12, ke Pengadilan Negeri, dengan alasan pihak pembeli (Tergugat) wanprestasi, pada saat itu Turut Tergugat juga menyatakan bahwa menurut ketentuan yang berlaku umum, tenggang waktu untuk melakukan pelunasan pembayaran jual beli tanah adalah paling lambat 1 (satu) bulan setelah dibuat/ditandatanganinya suatu APPJB. 


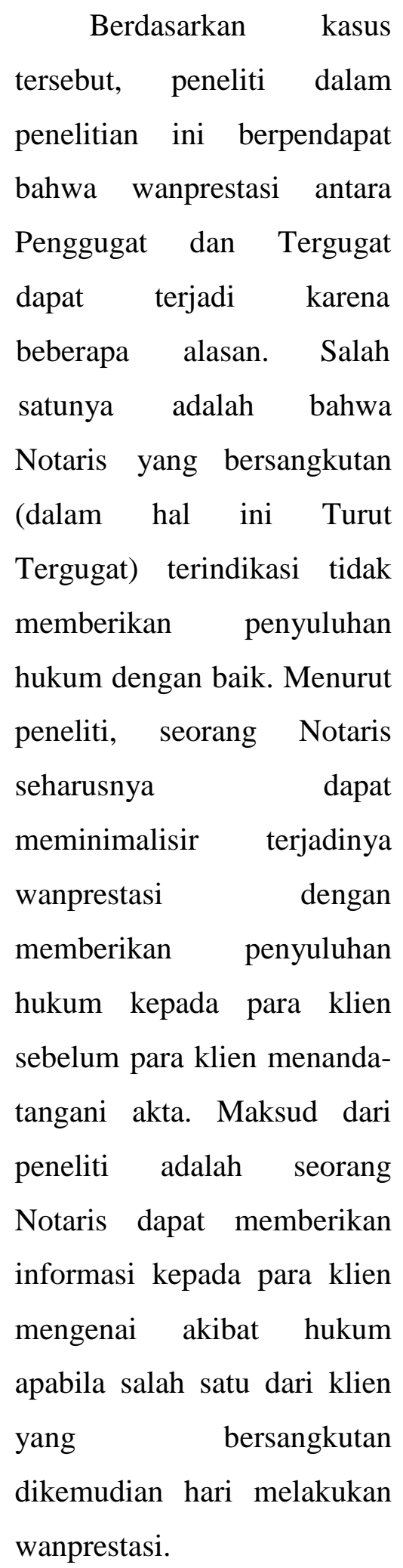

Dalam bahasa

Indonesia, Tanggung jawab adalah keadaan wajib menanggung segala sesuatunya (kalau terjadi apaapa boleh dituntut, dipersalahkan, diperkarakan, dan sebagainya). ${ }^{17)}$ Menanggung diartikan sebagai bersedia memikul biaya (mengurus, memelihara), menjamin, menyatakan keadaan kesediaan untuk melaksanakan kewajiban. ${ }^{18)}$ Tanggung jawab hukum adalah jenis tanggung jawab yang dibebankan kepada subjek hukum atau pelaku yang melakukan perbuatan melawan hukum atau tindak pidana. Sehingga yang bersangkutan dapat dituntut membayar ganti rugi dan/atau menajalankan pidana. ${ }^{19)}$

\footnotetext{
${ }^{17)}$ Kementerian Pendidikan dan Kebudayaan, "KBBI Daring”, https://kbbi.kemdikbud.go.id/entri/tanggung\% 20jawab, Diakses pada Tanggal 26 Maret 2019.

${ }^{18)}$ Kementerian Pendidikan dan Kebudayaan, "KBBI Daring", https://kbbi.kemdikbud.go.id/entri/menanggu ng, Diakses pada Tanggal 26 Maret 2019.

19) Salim HS dan Erlies Septiana Nurbani, Penerapan Teori Hukum Pada Penelitian
} 
Dengan demikian, dapat

diketahui bahwa tanggung jawab adalah suatu keadaan wajib menanggung yang dibebankan kepada subjek hukum yang melakukan perbuatan melawan hukum atau tindak pidana sehingga yang bersangkutan dapat dituntut untuk membayar ganti rugi dan/atau menjalankan pidana.

Menurut Ibu Dr. Lieke Lianadevi Tukgali, S.H., M.H., M.Kn., apabila terjadi masalah dikemudian hari akibat notaris tidak memberikan penyuluhan hukum sebelum pembuatan akta adalah notaris tersebut dapat menjadi turut tergugat dalam perkara yang bersangkutan. Menurut Bapak H. Nurdjaja, S.H., apabila terjadi masalah dikemudian hari akibat notaris tidak memberikan penyuluhan hukum dengan sengaja, maka akta tersebut dapat diminta

Disertasi dan Tesis Buku Kedua, (Jakarta: PT RajaGrafindo Persada, 2014), 208. pembatalannya ke pengadilan negeri setempat. Menurut Ibu Dr. Tjempaka, S.H., M.H., M.Kn., apabila notaris dianggap bersalah jika tidak memberikan penyuluhan hukum sebelum pembuatan akta, maka notaris tersebut dapat dikenakan sanksi yang diatur dalam Pasal 84 dan Pasal 85 UU Jabatan Notaris. Sebelumnya, notaris akan dipanggil oleh pihak MPD untuk dikonfirmasi dalam hal pembuatan akta yang bermasalah, jika sudah diketahui permasalahan tersebut maka pihak MPD akan merekomendasikan hasil dari permasalahan tersebut ke pihak MPW dan pihak MPW akan menyidangkan permasalahan tersebut dengan memanggil pihak notaris dan klien yang merasa dirugikan, setelah itu mengambil keputusan. Jika notaris tersebut dinyatakan telah melanggar kode etik maka 
dapat dijatuhi hukuman sesuai dengan Pasal 84 dan Pasal 85 UU Jabatan Notaris.

Sejalan dengan pendapat-pendapat tersebut, peneliti dalam penelitian ini berpendapat bahwa apabila terjadi masalah akibat seorang notaris tidak memberikan penyuluhan hukum kepada para pihak yang belum mengetahui mengenai hukum dalam hal akta yang akan dibuatnya secara disengaja, maka notaris tersebut bertanggung jawab atas akta yang dibuatnya. Dengan demikian, sanksi bagi notaris yang bersangkutan adalah notaris tersebut dapat menjadi turut tergugat dalam perkara yang bersankutan. Selain itu, notaris dapat dikenakan sanksi sesuai dengan Pasal 84 UU Jabatan Notaris yang menyatakan bahwa:

"Tindakan pelanggaran yang dilakukan oleh Notaris terhadap ketentuan sebagaimana dimaksud dalam Pasal 16 ayat (1) huruf i, Pasal 16 ayat (1) huruf k, Pasal 41, Pasal 44, Pasal 48, Pasal 49, Pasal 50, Pasal 51, atau Pasal 52 yang mengakibatkan suatu akta hanya mempunyai kekuatan pembuktian sebagai akta di bawah tangan atau suatu akta menjadi batal demi hukum dapat menjadi alasan bagi pihak yang menderita kerugian untuk menuntut penggantian biaya, ganti rugi, dan bunga kepada Notaris."

dan/atau Pasal 85 UU Jabatan Notaris, yang menyatakan bahwa:

\section{"Pelanggaran}

ketentuan sebagaimana dimaksud dalam Pasal 7, Pasal 16 ayat (1) huruf a, Pasal 16 ayat (1) huruf b, Pasal 16 ayat (1) huruf c, Pasal 
16 ayat (1) huruf $d$,

Pasal 16 ayat (1) huruf

e, Pasal 16 ayat (1)

huruf $f$, Pasal 16 ayat

(1) huruf g, Pasal 16

ayat (1) huruf h, Pasal

16 ayat (1) huruf $i$,

Pasal 16 ayat (1) huruf

j, Pasal 16 ayat (1)

huruf $k$, Pasal 17,

Pasal 20, Pasal 27,

Pasal 32, Pasal 37,

Pasal 54, Pasal 58,

Pasal 59, dan/atau

Pasal 63, dapat dikenai

sanksi berupa:

a. teguran lisan;

b. teguran tertulis;

c. pemberhentian

sementara;

d. pemberhentian

dengan hormat;

atau

e. pemberhentian

dengan tidak

hormat."

\section{PENUTUP}

\section{A. Kesimpulan}

Berdasarkan analisis pembahasan yang telah dilakukan, maka dapat ditarik beberapa kesimpulan terkait permasalahan yang diangkat, yaitu sebagai berikut:

1. Seorang notaris

mempunyai peran yang sangat penting dalam memberikan informasi terkait akta otentik agar akta otentik tersebut dapat dibuat sesuai dengan hukum yang berlaku, dan para pihak pun dapat merasa aman dan nyaman pada saat menjalankan perjanjian yang dibuat olehnya, serta para pihak memahami mengenai isi dari akta yang ditandatanganinya, karena berdasarkan Pasal 1338 KUH Perdata yang menyatakan bahwa: "semua persetujuan yang dibuat sesuai dengan undang-undang berlaku sebagai undang-undang bagi mereka yang membuatnya. Persetujuan itu tidak dapat ditarik kembali selain dengan 
Volume 17, No. 2, Oktober 2019

kesepakatan kedua belah

pihak, atau karena alasan-

alasan yang ditentukan

oleh undang-undang.

Persetujuan harus

dilakukan dengan itikad baik".

2. Seorang notaris dapat dianggap berasalah apabila notaris tersebut tidak memberikan penyuluhan hukum kepada para pihak yang belum mengetahui mengenai hukum dalam hal akta yang akan dibuatnya secara disengaja, maka notaris tersebut bertanggung jawab atas akta yang dibuatnya. Dengan demikian, sanksi bagi notaris yang bersangkutan adalah notaris tersebut dapat menjadi turut tergugat dalam perkara yang bersankutan. Selain itu, notaris dapat dikenakan sanksi sesuai dengan Pasal
84 dan Pasal 85

UU Jabatan Notaris.

\section{B. Saran}

Adapun saran yang dimunculkan oleh Peneliti dalam penelitian ini ditujukan kepada Notaris agar sebaiknya Notaris selalu memberikan penyuluhan hukum kepada klien terkait pembuatan akta karena tidak semua masyarakat memahami perbuatan hukum yang akan mereka lakukan. Selain itu, juga karena memberikan penyuluhan hukum kepada klien terkait akta merupakan salah satu dari beberapa tugas seorang notaris selain membuat akta dan hal tersebut diatur dalam UU Jabatan Notaris khususnya dalam Pasal 15 ayat (2) huruf e UU Jabatan Notaris, sehingga memberikan penyuluhan hukum merupakan salah satu cara untuk meminimalisir terjadinya permasalahan dikemudian hari, salah 
satunya

wanprestasi.

Kemudian, bagi masyarakat terutama masyrakat yang akan membuat akta, diharapkan dapat bertanya secara rinci kepada Notaris karena menurut Pasal 1338 KUH Perdata, akta yang sudah ditanda-tangani oleh para klien yang bersangkutan akan menjadi UndangUndang bagi mereka yang membuatnya sehingga para klien yang bersangkutan harus mengikuti hal-hal yang telah disepakati dalam perjanjian tersebut.

\section{DAFTAR PUSTAKA}

\section{A. Buku}

Adjie, Habib. Hukum Notaris Indonesia: Tafsir Tematik Terhadap UU No. 30 Tahun 2004 tentang Jabatan Notaris. Cetakan ke4. Bandung: PT Refika Aditama, 2014.

Anshori, Abdul Ghofur. Lembaga
Kenotariatan

Indonesia: Perspektif

Hukum dan Etika.

Yogyakarta: UII

Press, 2009.

Andasasmita, Komar. Notaris

Selayang Pandang.

Cetakan Ke-2.

Bandung: Bandung

Alumni, 1983.

Budiono, Herlien. Asas

Keseimbangan Bagi

Hukum Perjanjian

Indonesia, Hukum

Perjanjian

Berlandaskan AsasAsas Wigati

Indonesia. Bandung:

Citra Aditya Bakti, 2006.

Lubis, Suhrawardi K. Etika Profesi Hukum.

Cetakan Ke-10.

Jakarta: Sinar

Grafika, 2017.

S, Salim H. dan Erlies Septiana Nurbani. Penerapan Teori Hukum Pada Penelitian Disertasi dan Tesis Buku 
Kedua. Jakarta: PT

RajaGrafindo

Persada, 2014.

Soekanto,

Soerjono.

Pengantar Penelitian

Hukum. Cetakan ke-3.

Jakarta: UI Press,

2006.

dan Sri

Mamudji. Penelitian

Hukum Normatif

Suatu Tinjauan

Singkat. Jakarta: PT

RajaGrafindo

Persada, 2009.

Sudarsono. Kamus Hukum.

Cetakan ke-5. Jakarta:

PT Asdi Mahasatya, 2007.

Supriadi. Etika dan

Tanggung Jawab

Profesi Hukum di

Indonesia. Jakarta:

Sinar Grafika, 2006.

Tan Thong Kie. Studi

Notariat: Beberapa

Mata Pelajaran dan

Serba-Serbi Praktek

Notaris, Buku I,

Cetakan 2, Jakarta:
Ichtiar Baru Van

Hoeve, 2007.

B. Peraturan Perundang-

\section{Undangan}

Indonesia. Undang-Undang

Dasar Negara

Republik Indonesia

Tahun 1945.

- Undang-Undang

Republik Indonesia

No. 30 Tahun 2004

tentang Jabatan

Notaris (Lembaran

Negara Republik

Indonesia Tahun 2004

Nomor

117,

Tambahan Lembaran

Negara Republik

Indonesia Nomor

4432).

Undang-Undang

Republik Indonesia

No. 2 Tahun 2014

tentang Perubahan

Atas Undang-Undang

No. 30 Tahun 2004

tentang Jabatan

Notaris (Lembaran

Negara Republik

Indonesia Tahun 2014 
Nomor 3, Tambahan

Lembaran Negara

Republik Indonesia

Nomor 5491).

Undang-Undang

Republik Indonesia

No. 11 Tahun 2009

tentang

Kesejahteraan Sosial

(Lembaran Negara

Republik Indonesia

Tahun 2009 Nomor

12 ,

Tambahan

Lembaran Negara

Republik Indonesia

Nomor 4967).

C. Jurnal

Prasetyo, Ririk Eko. et al.

"Makna Pemberian

Penyuluhan Hukum

Oleh Notaris

Pembuatan Akta

Menurut Undang-

Undang Jabatan

Notaris". Lex

Humana Jurnal

Hukum dan

Humaniora. Volume

1 Nomor 1 Tahun

2016.
Sudjana."Penyuluhan

Hukum Dalam Upaya

Peningkatan

Kesadaran Hukum

Berlalulintas Melalui

Pemahaman

Terhadap Isi Undang-

Undang Nomor 22

Tahun 2009 Tentang

Lalu Lintas Dan

Angkutan Jalan".

Jurnal Pendidikan

Ilmu Sosial. Volume

25 Nomor 2 Tahun 2016.

D. Website

J, M. Rizal. "Pengertian Etika Profesi Menurut Para Ahli".

https://www.scribd.co $\mathrm{m} /$ document/3669458 32/Pengertian-Etika-

Profesi-Menurut-

Para-Ahli. Diakses

pada Tanggal 17

Februari 2019.

Jakarta, LBH. "Penyuluhan

Hukum LBH Jakarta

Di Rutan Salemba". https://www.bantuanh ukum.or.id/web/peny 
Volume 17, No. 2, Oktober 2019

uluhan-hukum-lbh-

jakarta-di-rutan-

salemba/. Diakses

pada Tanggal 1

Februari 2019.

Kementerian Pendidikan dan

Kebudayaan

Republik Indonesia,

"KBBI Daring".

https://kbbi.kemdikbu

d.go.id/entri/menangg

ung. Diakses pada

Tanggal 26 Maret

2019.

Kementerian Pendidikan dan

Kebudayaan

Republik Indonesia,

"KBBI Daring”.

https://kbbi.kemdikbu

d.go.id/entri/tanggung

\%20jawab. Diakses

pada Tanggal 26

Maret 2019. 